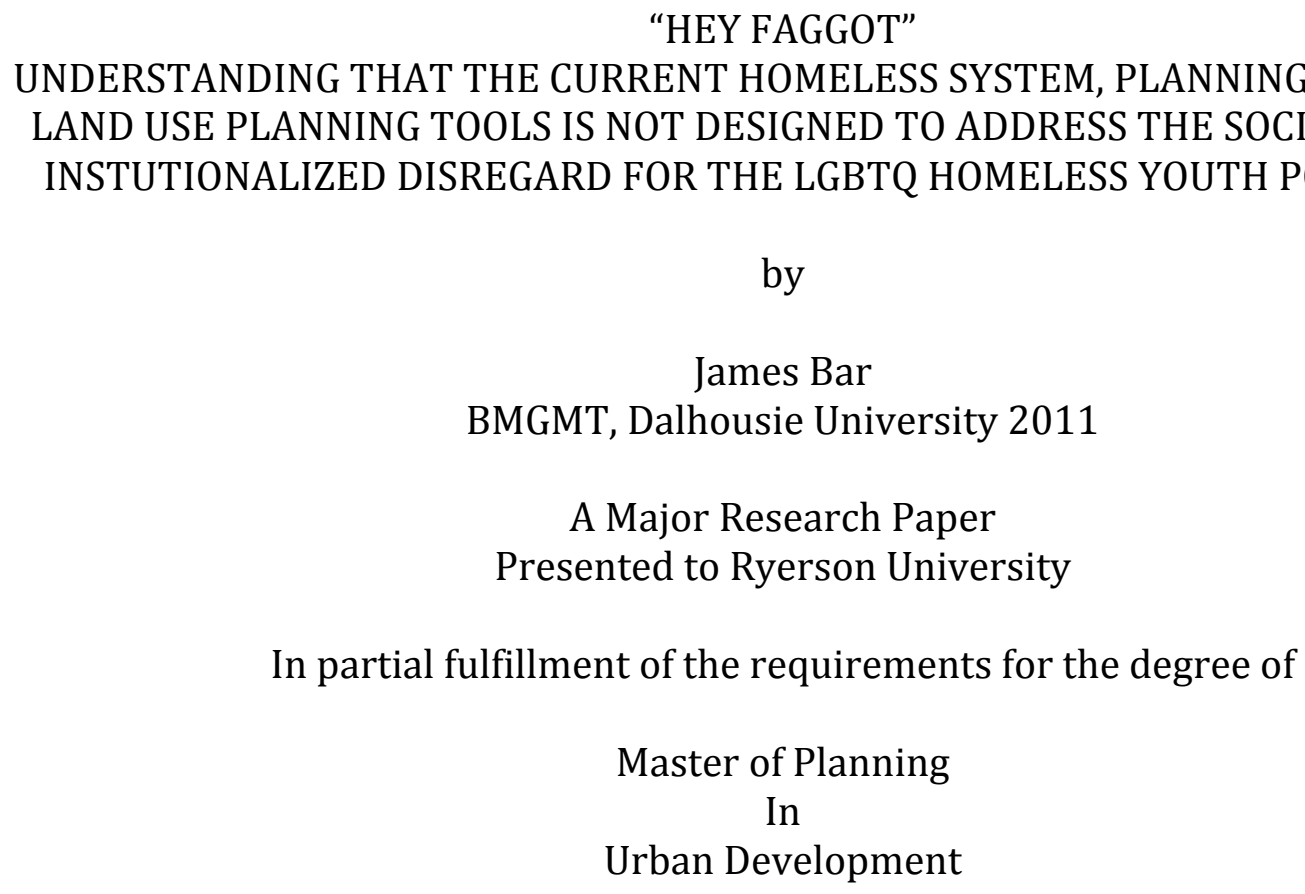

Toronto, Ontario, Canada, 2013

(C) James Bar 2013 


\section{Author's Declaration}

I hereby declare that I am the sole author of this major research paper. This is a true copy of the major research paper, including any required final revisions, as accepted by my examiners.

I authorize Ryerson University to lend this major research paper to other institutions or individuals for the purpose of scholarly research.

I further authorize Ryerson University to reproduce this major research paper by photocopying or by other means, in total or in part, as the request of other institutions or individuals for the purpose of the scholarly research.

I understand that my major research paper may be made electronically available to the public. 


\title{
"HEY FAGGOT" \\ UNDERSTANDING THAT THE CURRENT HOMELESS SYSTEM, PLANNING POLICY, AND LAND USE PLANNING TOOLS IS NOT DESIGNED TO ADDRESS THE SOCIALIZED AND INSTUTIONALIZED DISREGARD FOR THE LGBTQ HOMELESS YOUTH POPULATION
}

\author{
James Bar, 2013 \\ Master of Planning \\ In \\ Urban Development \\ Ryerson University
}

\begin{abstract}
Making up a disproportionate amount of the homeless youth population, LGBTQ homeless youth face a myriad of problems from increased depression and anxiety, emotional and belonging issues; higher rates of suicide, drug and alcohol abuse; and higher rates of STI and heath problems associated with increased rates of survival sex.
\end{abstract}

The findings, derived from a literature review, a review of current policies and land use planning tools in Toronto, interviews with two frontline homeless service providers and two policy workers, have brought to light areas where the profession of urban planning can contribute to reform the current system of shelter and support facilities.

Through language and skills training, provincial and municipal policy on housing and homelessness, land use planning tools of zoning by-laws and public consultations and the siting of facilities, and political backing, urban planning can help to aid in the provision of services for LGBTQ homeless youth.

\section{Key Terms}

LGBTQ - Lesbian, Gay, Bisexual, Transgender, Queer

Queer - An umbrella term for the LGBTQ population, as well as a means of selfidentification in the LGBTQ population 


\section{Acknowledgements}

Joseph Springer, my faculty supervisor. Thank you for your guidance, partnership, and shared passion for this topic.

Sharif Mahdy, my second reader. Thank you for your support, added enthusiasm, and knowledge about this field.

Sonya Reynolds. Thank you for guiding me through this large field of work pointing me towards numerous organizations across the city. 
Table of Contents

AUTHOR'S DECLARATION II

ABSTRACT $\quad$ III

KEY TERMS

ACKNOWLEDGEMENTS IV

\begin{tabular}{ll}
1.0 - INTRODUCTION AND CONTEXT & 1 \\
\hline
\end{tabular}

1.1 - LGBTQ YOUTH HOMELESSNESS

1.2 - TORONTO AND LGBTQ YOUTH HOMELESSNESS 1

1.3 - PLANNING AND SOCIAL ISSUES

1.4 - PLANNING AND LGBTQ YOUTH HOMELESSNESS 5

\begin{tabular}{lc} 
LANGUAGE & 5 \\
\hline
\end{tabular}

$\begin{array}{lr}\text { POLICY AND FUNDING } & 6\end{array}$

LAND USE Planning Tools $\quad 6$

\begin{tabular}{lr}
$2.0-$ METHODOLOGY & 8 \\
\hline
\end{tabular}

2.1 - LITERATURE REVIEW ON LGBTQ YOUTH HOMELESSNESS

COMING OUT AND LEAVING HOME $\quad 8$

ABUSE IN THE SUPPORT AND SHELTER SYSTEM $\quad 10$

HEALTH ISSUES FOR HOMELESS LGBT YOUTHS

TACKLING LGBT YOUTH HOMELESSNESS

2.2 - TORONTO'S POLICIES SURROUNDING HOMELESSNESS

ADDRESS THE ISSUE $\quad 17$

EVIDENCE AND REALITY $\quad 17$

VISION $\quad 18$

$\begin{array}{lr}\text { BUDGET } & 18\end{array}$

$\begin{array}{ll}\text { INDICATORS } & 18\end{array}$

2.3 - REVIEW OF EXISTING LAND USE PLANNING TOOLS

ZONING

$\begin{array}{ll}\text { Public Consultation } & 21\end{array}$

$\begin{array}{lr}2.3 \text { - INTERVIEWS WITH PARTICIPANTS } & 22\end{array}$

INTERVIEWS WITH POLICY AND PROGRAM PROFESSIONALS IN THE FIELD OF

HOMELESSNESS

WHAT IS YOUR KNOWLEDGE ON LGBTQ FOCUSED PROGRAMS AND SERVICE PROVIDERS IN THE CITY OF

TORONTO? WHAT ARE THE BARRIERS TO ACCESSING SERVICES IN THE CITY?

HOW DOES THE HEALTH OF LGBTQ HOMELESS YOUTH COMPARE TO THAT OF THEIR HETEROSEXUAL

COUNTERPARTS?

WHAT ARE THE FACTORS THAT PROLONG HOMELESSNESS? 
HOW CAN THE CURRENT DESIGN OF SHELTERS IN THE CITY BETTER REFLECT THE NEEDS OF LGBTQ HOMELESS YOUTH?

WHAT ARE THE CHALLENGES TO SITING NEW SHELTERS AND ASSISTED HOUSING UNITS? AND HOW CAN WE ALTER THE CURRENT DESIGN AND APPROACH TO THE SITING OF SHELTER AND SUPPORT FACILITIES? 27

\begin{tabular}{lr}
3.0 - DISCUSSION 29 \\
\hline
\end{tabular}

4.0 - RECOMMENDATIONS AND CONCLUSIONS

LANGUAGE $\quad 36$

POLICY AND FUNDING $\quad 37$

LAND USE PlanNING TOOLS $\quad 38$

\begin{tabular}{lr}
5.0 - LIMITATIONS & 40 \\
\hline
\end{tabular}

\begin{tabular}{lr} 
6.0 - WORKS CITED & 41 \\
\hline
\end{tabular} 


\section{0 - Introduction and Context}

\section{1 - LGBTQ Youth Homelessness}

Fifty percent of gay males experience a negative parental reaction when they come out, and $26 \%$ of those are met with a demand that the youth leave home (Ray, 2006, p. 16). Survival, identity, belonging, health issues; homelessness bring young people face-toface with new risks as well as exacerbating already existing issues in their lives (Walls, Potter, \& Van Leeuwen, 2009, p. 235).

Available data suggest LGBTQ young people are over-represented in the homeless youth population (Reck, 2009, p. 223). Based on a press release from Human Resources Development Canada, LGBT youth are thought to represent $25-40 \%$ of street youth in Canadian cities (Josephson \& Wright, 2000), which is out of proportion with the $1.1 \%$ of Canadians that identify as LGBTQ (Canadian Community Health Survey, 2012). Similar findings have been released in the USA, where the estimate is between 20 and $40 \%$, with some estimates as high as $50 \%$ of the homeless youth population (Ray, 2006, p. 13).

LGBTQ homeless youth face a myriad of problems from increased depression and anxiety, emotional and belonging issues; higher rates of suicide, drug and alcohol abuse; and higher rates of STI and health problems associated with increased rates of survival sex.

\section{2 - Toronto and LGBTQ Youth Homelessness}

Numerous cities in North America are seeing a rise in homeless queer youth, though it is not reflected in current policy and programming as shelters and faith based housing 
organizations do not adequately address the unique emotional and belonging issues of this population (Ray, 2006, p. 2).

Tackling the issue of homelessness in the City of Toronto is a seemingly daunting and ever challenging task. A staple in the urban fabric, homelessness is a prominent issue. Toronto has faced challenges generating public support to recognize and assist its homeless population. Former mayors of Toronto have declared that there are no homeless people in certain areas of the city only to wake up the next morning to find that a homeless woman has frozen to death in a bus shelter over night (Butt, De Gaetano, \& Thompson, 2004).

There exists shelter, support, and numerous outreach organizations in the city to aid in the everyday lives of these citizens. Through broad sweeping objectives in the Toronto Housing Charter, policy makers, planners, NGO's, faith-based organizations, and activists, have been working on policies and programs to assist this population as a whole. But these objectives ignore the nuance of specific populations that exist within the homeless community.

Addressing lesbian, gay, bisexual, transgender, and queer (LGBTQ) homelessness in the City of Toronto has not been a priority for this is constantly seen through a lack of recognition by formal channels. This young, vulnerable population is underserved by support agencies and underrepresented in the current homeless lexicon.

Every year, thousands of homeless youth stay in shelters in Toronto (CMHC, 2001). The current system of shelter support and programs is not designed to address the stigmas and hate directed at LGBTQ homeless youth, and as a result, queer homeless youth end up on the streets rather than in a system of care. 
There are numerous city programs aimed at helping homeless youth in the City of Toronto (Streets to Homes, Youth Shelter Support, Housing Help and Follow-up, Employment and Training, Aboriginal Youth Programs), and while the Sherbourne Health Centre caters to the health needs of the LGBTQ community, there are no designated shelters or transition programs aimed directly at serving the LGBTQ homeless youth in Toronto.

There has already been one push to create an LGBTQ homeless shelter in the City of Toronto but with no results. Titled "House Call," a series of community conversations were held to build a movement to create a shelter for homeless LGBTQ youth.

Toronto's housing charter outlines the policies that serve as a guide for City Council and the public service on how to aid in the provision of delivering services for all its citizens to provide access to safe, secure, affordable, living spaces and outreach programs free from bias and discrimination (City of Toronto, 2009). Regardless of whether they rent, own, or are homeless, they all have an equal stake and voice in Toronto's future.

The social challenges faced by cities like Toronto are complex and nuanced and cannot be addressed broadly in policy and programming. Toronto is not new to the game of creating action on social issues. Recognizing and tackling the issue of LGBTQ youth homelessness in the city will take the coordination of policy and programming, leveraging of land use planning tools, as well as funding and the political will to elevate the issue. 


\section{3 - Planning and Social Issues}

The correlation between public health issues and urban planning interventions is strong. Planning is rooted in public health and safety, dating back to its early triumphs with its role in sanitation and separation of unfavorable land uses, exemplified by John Snow's mapping of cholera outbreaks to contaminated wells from sewage in London, England. Planners responsibility to the public is to ensure a healthy and livable space for everyone that inhabits them. Through policy direction, planning interventions, and design solutions, urban planners have long been intervening in urban affairs.

Planners are change agents, charged with representing societies' best interests, they aid in the provision of services and social equity through management of the built form and recognition and action on societal issues. The role of the planner is to not just recognize the issues at hand, but to develop policy creation and implementation, comprehensive planning interventions, and design solutions. Planners are guardians of public health and aid in the provision of services.

Toronto is not new to reacting and working to solve social ailments with planning interventions. Saul Betsch's sexual assault and murder of the 12-year-old Toronto shoeshine boy Emanuel Jacques in 1977 shocked the city and led to protests and pressure on politicians to clean up Yonge Street (OMNI). It was this pressure that led politicians and urban professionals to revitalize the seedy Yonge Street Strip by shutting down body rub parlors and clearing out undesirable businesses for the creation of Yonge-Dundas Square.

With Cabbagetown gentrifying in the 1970's and 1980's, there was a push to remove prostitution from the neighbourhood. Through redirecting traffic movement of the 
numerous one-way streets, it became inconvenient for 'tricks' to drive through, pushing the business out of the neighbourhood.

Most recently, urban planning has reacted to remediating its own outdated intervention. Urban planners have begun to revitalize Regent Park, the large 1940's social housing project, attempting to reduce social alienation through environmental design by reconnecting the street grid with the larger city, rebuilding the urban fabric, and introducing services back into the neighbourhood.

\section{4 - Planning and LGBTQ Youth Homelessness}

Planners have a dynamic expanded vision. The role of the planner is to recognize the issues at hand, and develop policy creation and implementation, comprehensive planning interventions, and design solutions, giving planners a broad perspective on how to address LGBTQ youth homelessness. Planning responses need to be proactive and collaborative, utilizing policy to aid in the provision of services. Policy begins by formally recognizing the issue at hand, outlining how a society has chosen to address and remediate the issue.

Coupled with research, there are three main areas of focus where urban planners can aid in the provision of services for LGBTQ homeless youth; language, policy and funding; and through land use planning tools.

\section{Language}

Language skills training alone cannot be addressed directly through planning interventions. This does not mean planners are excused from language comprehension and knowledge of the issues, as they must possess the skills and knowledge in order to write effective policy and secure funding. They will also need to interact with LGBTQ 
homeless youth in order to create interventions using municipal land use that reflect the needs of the community.

Planners, when bringing their expertise outside the realm of traditional land use planning, must be able to communicate and use particular language skills that pertain to the subject at hand in order to write effective policy.

\section{Policy and Funding}

Policy should clearly address the issue it is hoping to affect, and be supported by evidence such as statistics, best practices, and professional opinion. Effective policy should include a vision and action plan with a clear source of funding for obtaining policy objectives. They should also include a means to measure how a policy is being achieved through its projects and programs. Currently this is lacking in the municipal policies with regard to LGBTQ youth homelessness. Not only can policy be a reflection of societies values and ideals, policy lays the groundwork for program delivery, design, and funding to aid in the provision of services.

\section{Land use Planning Tools}

Planning processes need to be clear, equitable, and have the greater needs of society in mind. Toronto needs to look towards the creation of an LGBTQ focused shelter and support services, utilizing municipal land use planning tools through the reworking of zoning by-laws to include shelters as-of-right across the city.

The public process for siting of new facilities should include all stakeholders, but the current municipal planning tools of zoning by-laws and public consultations favour property owners and discourage the siting of new shelter and support facilities.

The planning process itself, designed to give everyone a chance to be heard, is actually hindering the placement of new shelters based on the interests of a few actors with a 
perceived greater interest. Planners need to recognize this limitation and act not in the interests of a small few, but for the greater public good. 


\section{0 - Methodology}

There are three methods employed to explore the subject of LGBTQ youth homelessness, each addressing an area that the profession of planning can address to strengthen its approach.

By analyzing accounts of discrimination and abuse in the system through a literature review, it will bring forward the issues and challenges facing LGBT homeless youth is not adequately reflected in the current outreach and programs in place.

Examining the current youth housing and homelessness policies and programming in the City of Toronto to pinpoint where professionals can address the problem in language and service delivery, and review existing land use planning tools to further highlight where urban planning can take action to ease the siting of shelters and support facilities.

Through key informant interviews with frontline workers and policy professionals, valuable insight into how professionals in the field view LGBT homelessness in the larger context of homelessness, and the potential policy directions and service options that can be utilized to begin alleviating the plight of queer homeless youth.

\section{1 - Literature Review on LGBTQ youth Homelessness}

\section{Coming out and Leaving Home}

While most people believe that an individual is born either straight or gay, there are some who still believe that it is a personal choice to be homosexual (Ordover, 1996)(Greenberg, 2007). There is also a misconception amongst youth that homosexual individuals present a threat to heterosexuals (Sharpe, 2002). Boys and girls, aged 11-17, found a majority of males stating that homosexuality is always wrong (Sharpe, 2002, p. 264), specifically with the physical sexual aspects of gay or lesbian relationships 
strongly bothering the young people (Sharpe, 2002, p. 266). Homophobia among young people plays a major part in enforcing gender conformity, and thus in the construction of heterosexuality (Sharpe, 2002, p. 266).

Dehumanization allows people to suppress emotions that they would normally feel toward other human beings (Lammers \& Stapel, 2011, p. 114). Although this might seem cynical, this also means that dehumanization is functional, and without the ability to dehumanize, people would see their victims as humans like themselves with similar qualities as themselves (Lammers \& Stapel, 2011, p. 114). As a result, they would experience feelings of empathy and compassion if they were to abuse these people or otherwise cause pain and suffering (Lammers \& Stapel, 2011, p. 114). Because everyday dehumanization can help to justify decisions that are painful, people dehumanize for a specific purpose. A crucial part of dehumanization is that it leads people to ignore the individual viewpoints of others (Lammers \& Stapel, 2011, p. 115).

Fifty percent of gay males experienced a negative parental reaction when they came out, and twenty six percent of those disclosures were met with a demand that they leave home (Ray, 2006, p. 16). Young queers face a myriad of abuse at home. They face higher rates of sexual assault (Ray, 2006, p. 19), with 40 to 60 percent of all homeless youth stating physical abuse contributed to their no longer living at home (Ray, 2006, p. 18). Conflict and abuse at school - of which $80 \%$ of LGBTQ youth report facing - further increases the likelihood of homelessness (Ray, 2006, p. 20). Youth fear that because their sexual orientation or gender identity will disappoint their parents, they need to find an alternative space where they can be respected and optimize their chances of succeeding in life (Ray, 2006, p. 20). 
If a youth is thrown out of their home or runs away in their late teens, they may not be placed in foster care before aging out of the system (Hunter, 2008, p. 544). Additionally, social service agencies may decline to place older youth with foster families, and many of those LGBTQ youth who are placed in foster care ultimately run away because of abuse in the foster home; ending up on the streets (Hunter, 2008, p. 545). Consequently, as many as seventy-eight percent of LGBTQ youth in foster care run away, which helps account for the fact that sixty percent of homeless LGBTQ youth were previously in foster care. (Hunter, 2008, p. 545). Homelessness brings young people face-to-face with new risks as well as exacerbating already existing issues in their lives (Walls, Potter, \& Van Leeuwen, 2009, p. 235).

\section{Abuse in the Support and Shelter System}

The faith based youth shelters in the city (City of Toronto, 2008) are not set up to deal with the prejudice against the LGBTQ population and the unique emotional needs of young queers, with some refusing service to out queer individuals (Ray, 2006, p. 86). Additionally, queer youth are less likely than their heterosexual counterparts to use faith based services, indicating that they are less receptive to LGBTQ individuals (Ray, 2006, p. 86). This demonstrates that it is possible that LGBTQ youth might put off seeking help if they believe that their only option is a potentially anti-LGBTQ service provider (Ray, 2006, p. 85).

Fifty percent of LGBTQ youth in homeless youth emergency housing programs are physically assaulted (Hunter, 2008, p. 545). Many homeless LGBTQ youth choose to live on the streets or exchange sex for a place to stay rather than continue to face the pervasive anti-LGBTQ physical abuse, intimidation, and denigration which they encounter in homeless youth housing programs (Hunter, 2008, p. 545). 
Eighteen-year-old Kelly R. was homeless. At the age of sixteen, her parents kicked her out of her home because she is transgender. Subsequently, she ran away from the group home in which she had been placed by the Administration for Children's Services (Hunter, 2008, p. 543). When the weather got too cold for her to sleep outside and she could not earn enough money from prostitution to rent a hotel room, she stayed at a large emergency youth housing facility in lower Manhattan. The staff regularly forced her to bathe in an open showering facility with the shelter's male occupants (Hunter, 2008, p. 543). One day in the shower, a group of these males attacked her. They beat her against the cement floor until her entire body was inflamed with contusions. They did not stop until her jaw was ripped from her face. This all occurred with staff present (Hunter, 2008, p. 543).

At one residential placement facility in Michigan, LGBTQ teens, or those suspected of being LGBT, were forced to wear orange jumpsuits to alert staff and other residents (Ray, 2006, p. 5). At another transitional housing placement, staff removed the bedroom door of an out gay youth, supposedly to ward off any homosexual behavior. The second bed in the room was left empty and other residents were warned that if they misbehaved they would have to share the room with the "gay kid" (Ray, 2006, p. 5).

\section{Health Issues for Homeless LGBT Youths}

Problem behaviors such as alcohol or drug use, risky sexual behavior, or involvement with the criminal justice system are strong predictive factors influencing acceptance of LGBT homeless youth back to their families. The greater the level of such behavior at the point of homelessness and the greater the increase in such behavior over the course of the following 12 months, the less likely strong familial bonds that might draw a young person home would endure (Ray, 2006, p. 22). The lifestyle of homeless youth puts their 
health at risk; and the longer a person is homeless, the worse his or her health becomes (CMHC, 2001).

Homeless sexual minority youth appear to be more likely to engage in survival sex than homeless heterosexual youth, particularly for homeless bisexual and gay male youth (Walls, Potter, \& Van Leeuwen, 2009, p. 241). The likelihood of engaging in survival sex appears to increase with age among gay- and bisexually-identified street youth (Walls, Potter, \& Van Leeuwen, 2009, p. 242).

In Toronto, HIV/AIDS, Hepatitis $\mathrm{B}$ and $\mathrm{C}$, and suicide are serious concerns for the homeless youth population (CMHC, 2001); and these problems amplify for young LGBTQ youth. Queer homeless youth have higher rates of HIV contraction and over twice the rates of sexual victimization than their heterosexual counterparts (van Leeuwean, et al., 2006, p. 155).

Substance abuse is more common with LGBTQ homeless youth (van Leeuwean, et al., 2006, p. 162). There was also a higher proportion of LGBT youth trying cocaine; crack or freebase; ecstacy; cigarettes; marijuana; alcohol; ketamine; mushrooms; GHB; PCP; heroin; methamphetamines; DMX and Coricidin; Calium; Librium; Xanax; LSD; and Morphine, Codeine, Vicodin, or Demerol (van Leeuwean, et al., 2006, p. 162). Social stigma is a potent force behind the substance abuse problems of LGBTQ homeless youth. LGBTQ youth in general experience chronic stress that is inflicted by peers and family members in the form of verbal and physical abuse (Ray, 2006, p. 49). However, this verbal and physical abuse is associated not only with increased substance abuse by LGBTQ youth but also with negative outcomes including school related problems, 
running away from home, conflict with the law, prostitution and suicide (Ray, 2006, p. 49).

Mental health issues are experienced by sexual minority youth at a rate higher than their heterosexual counterparts including suicidal ideation and attempts (Walls, Potter, \& Van Leeuwen, 2009 , p. 238). One study found that $53 \%$ of the homeless gay male youth reported at least one suicide attempt compared to $32 \%$ of the general homeless male youth participants (Kurks, 1991). These stressors may include feelings of being different from their peers, isolation both in their lives and in their school experiences, victimization and ridicule because of sexual orientation, rejection by peers or family because of sexual orientation societal oppression and discrimination and actual violence (Walls, Potter, \& Van Leeuwen, 2009, p. 239). Those who identified as sexual minority were almost three times as likely to have reported a suicide attempt as those who identified as heterosexual (Walls, Potter, \& Van Leeuwen, 2009, p. 245).

Racialized queer youth also face abuse both in the system and on the street. Gay villages are areas mostly inhabited by non-racialized middle class queers (Reck, 2009, p. 235), making racialized youth feel excluded. Extensive institutionalized and interpersonal exclusions position racialized queer youth as outsiders, and deny them needed community resources (Reck, 2009, p. 235). LGBTQ youth of coluor also often face the dual dilemma of homophobia within their ethnic communities, and racism from white gay communities (Reck, 2009, p. 239). They also face higher levels of police and community harassment (Reck, 2009, p. 236).

Some adult gay community members participate in the exploiting of homeless youth for sex (Reck, 2009, p. 237). "Chickenhawks" - term for an older gay man that prefers 
younger male partners - use underage boys for their sexual pleasure, taking advantage of their disadvantaged position and need to acquire resources to survive. Survival sex is especially risky for trans youth, as they risk being "found out" by a trick and risk physical abuse in order to obtain money or shelter (Reck, 2009, p. 234).

\section{Tackling LGBT Youth Homelessness}

Tackling the issue of LGBTQ homelessness is not easy, and requires overhauling the current approach to dealing with homeless youth. Family outreach and the promotion of positive parenting in the context of homelessness can provide mentoring for parents and attempt to get LGBTQ youth off the street (Cowan, Gewirtz, Haskett, Perlman, \& Stokes, 2012).

The unstable and violent conditions faced by LGBTQ homeless youth in shelters and on the street decrease their prospects of transitioning into stable living arrangements (Hunter, 2008, p. 546). LGBTQ youth are significantly more likely to be involved in child welfare than their non-LGBTQ counterparts, identifying a need to outfit child-welfare providers with the needed tools and training to make the system more safe and welcoming for LGBT youth (van Leeuwean, et al., 2006, p. 165). Without such practices in place, as soon as an LGBT youth runs away from the system of care, their respective public health risks are significantly greater than non-LGBTQ youth. Recognizing that simple changes to the operations of the shelter system would directly benefit LGBTQ homeless youth in the system, as well as other homeless youth could drastically enhance the overall effectiveness of the system.

Ernt Hunter, in his report, What's Good for the Gays is Good for the Gander: Making Homeless Youth Housing Safer for Lesbian, Gay, Bisexual, and Transgender Youth, recognizes that simple changes to the operations of the shelter system would directly 
benefit LGBTQ homeless youth in the system (Hunter, 2008, pp. 549-552).

(1) Placing low maximum limits on the occupancy capacity at which these programs may operate;

(2) Requiring that all showering facilities provide individual privacy;

(3) Prohibiting anti-LGBT discrimination in the provision of services;

(4) Requiring nondiscrimination and sensitivity training;

(5) Promoting the creation of LGBT-specific homeless youth housing programs.

Politics may also play into these kinds of decisions. Some believe that the lack of an accurate count of the nation's homeless population provides an excuse for politicians and public policy administrators to avoid dealing with the issue comprehensively (Ray, 2006, p. 15). Advocates for homeless people and politicians have often clashed over how many people experience homelessness and the funds needed to serve them appropriately (Ray, 2006, p. 15).

While there exist shelters and transitional living spaces for LGBTQ homeless youth in New York City and Detroit, no such places have been constructed in Toronto. And while the city of Toronto has the Housing Charter - Opportunity for All (City of Toronto, 2009) and programs designed to assist homeless youth populations (City of Toronto, 2008), LGBTQ youth still face discrimination in the institutionalized support system, and therefore are not adequately accounted for in the policy and programming of the City.

\section{2 - Toronto's Policies Surrounding Homelessness}

Policy is an adopted principle or action, implemented through programming, using projects to implement specific directed initiatives. The objectives outlined in policy are realized through programs and projects, which are initiated through the budget process (NICVA, 2011). From affordability, discrimination, and homelessness, housing policy sets the overarching goals that a city wants to reach. 
The City of Toronto has outlined in the Toronto Housing Charter, the policy framework that is needed to address shelter related issues in the city. Through Shelter, Support and Housing Administration Division, the City of Toronto looks after a wide variety of issues surrounding homelessness, program support, the Streets-to-Homes program, tenant landlord resources, social housing, community initiatives, and hostel services. The Division also provides and funds a variety of programs to help homeless and street involved youth (City of Toronto, 2009).

The Division supplies a range of outreach services, from shelters with comprehensive supports, to training and employment opportunities and housing. This includes a new partnership proposal to renovate or repair existing transitional housing to support homeless people who are moving from the streets or shelters into stable housing (Shelter, Support and Housing Administration , 2012).

In the How Toronto Is Solving Youth Homelessness report, the city has outlined several programs and projects directed towards helping homeless youth in Toronto with the Streets to Homes, youth shelters, housing help and follow-up, and employment and training skills programs. Special programs have also been developed for lesbian, gay, bisexual, transsexual and transgender (LGBT) youth and Aboriginal youth (City of Toronto, 2008).

There are five key characteristics of effective policies (NICVA, 2011). And housing policy needs to address these five characteristics in order to fully tackle the issue of LGBT homelessness.

1. Clearly address the issue that it is hoping to affect; 
2. Be supported by evidence. Statistics, current best practices, knowledge of best practices, and professional opinion;

3. Have a vision for attaining the objectives of the policy and action points should flow from this;

4. Clear funding as policies with budgets are more attractive to departments than polices without budgets;

5. A means to measure how the policy is functioning through its programs and projects.

(NICVA, 2011)

\section{Address the Issue}

In the report How Toronto Is Solving Youth Homelessness, they provide a clear synopsis and outline on how the City is working to solve youth homelessness. Provided in the report is a detailed description for each unique initiative, except one for LGBTQ youth homeless issue. The Shelter, Support and Housing Administration Division outlines the Sherbourne Health Centre's Supporting Out Youth Program that aims to directly address immediate housing, food and transportation needs while providing emotional and social supports (City of Toronto, 2008). But there is no policy or program by the City that address the issue of LGBT youth homelessness directly. While the report does outline special programs developed for LGBTQ homeless youth, these programs are not City initiatives.

\section{Evidence and Reality}

There is no evidence of the level of LGBT homelessness in the youth homelessness population by the City of Toronto. Based on a press release from Human Resources Development Canada, LGBT youth are thought to represent $25-40 \%$ of street youth in Canadian cities (Josephson \& Wright, 2000), yet the City does not recognize this in their own policy. Furthermore, there is no recognition of current programs in other jurisdictions, documented knowledge of the rise in recent years of LGBT youth in the homelessness youth populaiton. 


\section{Vision}

There is little vision for LGBTQ programs, as it does not state a starting point, deliverables, or end objective. And with no form of evidence as to how many LGBT youth there are on the streets to support initiatives of the program, it becomes harder to craft a vision and strategy with a lack of a realistic concept of the current state of affairs. The policy does not address the major concern of LGBT youth homelessness, and does not put forward any action plan to begin to remediate the terrible situation facing these young and disadvantaged members of the homeless population.

\section{Budget}

Currently, through the Shelter, Support and Housing Administration Division, there exists little indication of direct funding or resource allocation. The programs at the Sherbourne Health Centre that deal with the physical and mental health of LGBT youth and homeless youth are funded through the Ontario Ministry of Health and Long Term Care; as well as private donations and support and contributions from the City of Toronto's Supporting Community Partnerships Initiative and several other charitable organizations. Proper funding for programs and projects is what gives policy teeth, the means to enact the changes it wishes to see in a society.

\section{Indicators}

There currently exists no set of measurable targets to assess whether the LGBTQ policy actions are effective. Policies must have actions, and targets must match these, otherwise they are simply statements of opinion. Effective targets need to be set, and the should be clear on what they want to achieve, outlining a timeframe by which to achieve intended results (NICVA, 2011).

\section{3 - Review of Existing Land Use Planning Tools}

Using the existing municipal planning tools of zoning by-laws and community 
consultations, urban planners can engage the public and manage land uses across the city. Land use planning tools implement policy. Planning and design solutions must take into consideration integrating policy analysis, and an awareness of the spatial activities of different social groups, into their design work (Kerkin, p. 35).

Municipalities are limited in their abilities to address the issues they are required to resolve. Constrained budgets, long political processes, and a lack of tools, inhibit planning's ability to remediate social issues through existing planning tools as the existing process favours those with legal land rights. Using zoning by-laws and community consultations, planners can design and site facilities, retrofit existing buildings, and construct new buildings. All of these potential changes are subject to the interests of the community and the political process. Solutions must be place specific, realizing the interplays between policy, programming, an policies.

\section{Zoning}

Because municipalities must often rely heavily on zoning, matters that might be better suited to other types of legal solution, if brought before a municipality, end up funneled into zoning and planning mechanisms (Ranasinghe \& Valverde, 2006, p. 327). The problems rigid prescriptive zoning by-laws present are exacerbated when municipalities are forced to address matters of social justice, in particular, homelessness.

A zoning by-law controls the use of land in a community. A zoning by-law states how the land may be used, where buildings and other structures can be located, the types of buildings that are permitted and their use, and the lot and building dimensions (Ministry of Municipal Affaris and Housing, 2010). 
The zoning by-law implements the objectives and policies of a municipality's official plan and contains specific requirements that provide a legally enforceable way to manage land use and future development. Outlined by the Ontario Ministry of Municipal Affairs and Housing, zoning also protects a person from conflicting and possibly dangerous land uses in a community, with zoning taking into consideration adjacent land uses and suitability of a new use in existing areas.

These laws surrounding land use have never been about equity or social justice but more concerned with the protection of property, regulating undesirable uses of land, and segregating and compartmentalizing spaces according to uses (Ranasinghe \& Valverde, 2006, pp. 327-328). Shelters, transitional housing, and human care facilities are controversial land uses, generally recognized as being needed, however, they are seen as undesirable neighbouring land use and encounter opposition at the neighbourhood scale (Kuzmak \& Muller, 2010).

Land uses, which provide some solace to the very poor (halfway houses, shelters, supportive housing) have no rights (Ranasinghe \& Valverde, 2006, p. 326). The fact that land uses have no rights is crucial to the municipal shelter by-law story and other efforts to provide housing for the homeless in general (Ranasinghe \& Valverde, 2006, p. 327). Given that the homeless have no property to call their own, they are peremptorily excluded from relying strictly on a rights based approach (the right to shelter), because rights, in land use law, are tied to uses and not directly to persons. Thus in land use law and municipal politics, planning can do very little to provide meaningful solutions for many homeless people (Ranasinghe \& Valverde, 2006, p. 327). 
Inclusionary zoning has been cited as a means to increase the ability of municipalities to build shelters and support facilities as-of-right in specified zones across a municipality. Being able to build shelter across the city will give local patrons the ability to access shelter services and keep them within their community (Ranasinghe \& Valverde, 2006, p. 332). But in Toronto, where some shelters have been built, zoning provisions prohibit shelters from being built within $250 \mathrm{~m}$ of each other because they are defined as crisis facilities.

Section 37 of the Planning Act, whereby municipalities attain community benefits from private sector developments offers potential, however, there have been extremely little shelter, assisted and transitional housing units created (Mah, 2009).

\section{Public Consultation}

Public participation and rights were installed into Toronto planning in the 1960's as citizen groups were fed up with how experts were imagining changing their neighbourhoods. The principles of public consultations in Toronto are openness, transparency, inclusion, and accessibility (City of Toronto, 2004), but public consultations and public input make it difficult to implement meaningful solutions for the homeless and precariously housed. While public consultations and input do create a dialogue, the process and outcomes tend to give the greatest influence to those who have legal property rights within proximity to a subject site (Ranasinghe \& Valverde, 2006, pp. 328-329).

Arguments for shelters based on rights and land rights are hard fights to win for advocacy groups, because the surrounding land rights of their owners hold greater value 
than rights argued for in the constitution. It is an argument of who bears the "burden" of a new shelter and the questions of, "why this site, why this neighbourhood, why now?"

Planners need to understand the context in which their decisions are being made. Every community, every neighbourhood, every street is different but only the sum of all the parts can equal the greater public interest. Sandercock (2007) argues that if planning's constituency is to continue to be, at least in part, those groups who are most vulnerable, whether from economic or political disadvantage or from cultural discrimination and oppression, then new forms of planning will be increasingly important and planners will need greater design and issue literacy in order to work effectively in the multi-ethnic, multi-racial cities and regions of the next century (Kerkin).

\section{3 - Interviews with Participants}

Interviews were conducted between 13 March and 02 April 2013. The importance of the interviews for this research topic was to gain primary knowledge from those working directly with the population in Toronto.

Two interviews with frontline workers with first hand knowledge and experiences from interacting with LGBT homeless youth, bring forward barriers they perceive LGBT homeless youth face and ways we can build a stronger system of care that meets the needs of the population. As well, two interviews were conducted with policy workers to highlight the challenges facing the shelter and support system surrounding political support, policies, and the planning process. Each participant was asked a standard set of questions. Below, their answers have been synthesized and arranged according to the questions posed to them. 


\section{Interviews with Policy and Program Professionals in the Field of Homelessness}

What is your knowledge on LGBTQ focused programs and service providers in the City of Toronto? What are the barriers to accessing services in the city?

Interviews with professionals in multiple organizations that work on the front lines with homeless youth and LGBT homeless youth noted that there is a lack of LGBT focused programs across the city, and some admitted that their knowledge of specific LGBT focused programs was limited. But the programs that are available retain young people as they are serving needs that were not being met somewhere else. One policy worker noted that, "we do not have any that are designed for LGBT youth."

It was noted that it [our society] is a very "heterocentric society," and that people make a lot of assumptions about sexuality. One participant stated that, "within the street involved community, there are a lot more young people and old people that are engaged in relationships with same sex people than people actually think."

In one interview, one person noted that:

"There is a disproportionate amount of people in the youth homeless population that identify as LGBTQ. There is an understanding that around $10 \%$ of the population is LGBTQ, but around $40 \%$ of the homeless youth population identifies as LGBTQ, and there is not adequate support in order to deal with this population."

All of the interviewees stated that there was a lot of homophobia and transphobia in the shelter system and that youth who did speak to them said there was a lack of response from care providers in dealing with homophobia and transphobia when it did arise. And though there has been training work conducted, there is still a lack of understanding and knowledge amongst the staff on how to best work with and communicate with this community, as currently, shelters and support facilities do not feel like safe spaces for LGBTQ homeless youth. 
There needs to be greater resources to support young LGBTQ youth to live independently. While there exists no shelter for LGBTQ homeless youth in Toronto, there also exists little transitional and assisted housing. Toronto is a fairly unaffordable city to rent in, and those looking for housing for the first time may not be able to afford to live in the spaces they need to.

Many service providers and front line workers are still scared of LGBTQ people and LGBTQ issues. They do not know how to address homophobia or transphobia when it arises in front of them when homeless youth or the service providers themselves say something homophobic. One service provider said that, "Something homophobic, when said left unaddressed, can make another person feel terrible. Language can attack and violate a person, and if they do not feel safe, they will leave and not return."

In one interview, a frontline worker noted that, "homophobic language is like sexist language and it all comes from the same bigoted place.' Current service providers not schooled on how to talk to or address LGBTQ people on their level, or be comfortable with the language, are barriers because they cannot connect with the person. It is tone or body language that set the stage. If a scared, homeless, abandoned LGBTQ youth does not feel comfortable, they will not stay and they will attempt to find services elsewhere. They may have services and stuff that youth want, but the way they lay out the menu off putting and the person turns away from those services.

Another noted barrier in Toronto were Christian service providers. As they aimed to help the disadvantaged, helping people if they followed a certain set of rules which did not align with those of the LGBTQ community. One of the service providers noted that 
they were attempting to have their staff better reflect the homeless population by hiring a more diverse staff that can address these issues.

For resource access, one participant noted that:

'It is not clear to folks where to access resources. There is a real shortage of clearly outlined and accessible information. City language is not clear and confusing. It is like navigating a zoning by-law sign with 4000 words of text with no clear indication of who to contact or how. They should be easier to read and designed like a shoe add, which are clear and informative on what you are getting, how much it is and where to access it.'

\section{How does the health of LGBTQ homeless youth compare to that of their}

\section{heterosexual counterparts?}

All service providers noted that the health, both mental and physical, of LGBTQ homeless youth is generally worse than their heterosexual peers. One of the participants noted that, "homelessness does not help a persons health in any regard, regardless of sexual orientation, race, or gender construct. It is hard to be healthy when you are homeless." LGBTQ homeless youths physical health is compromised as they have less available shelters, less food bank options.

All participants noted that these mental ills are compounded with a lack of housing. Their emotional health is especially compromised, with higher levels of anxiety and depression. One front line employee noted that youths making the choice to go back into the closet for shelter and meals (if they were lucky enough to be able to mask their sexuality), and constantly looking over their shoulder in fear of physical harm, can be both mentally and emotionally draining. Segregation and marginalization impacts a person's mental heath, as new community and new family are hard to build. 
What are the factors that prolong homelessness?

Interviewees noted that there were several factors that increased prolonged homelessness in youth. Skills and education, resources, and lack of affordable living spaces all prolonged a youths time on the streets and in the care system.

In an interview with one front line employee, they noted that classism kept the youth homeless, and that the only youth to make it off the street are the ones that can "fake it until they make it." If they do not enter the streets with some skills and knowhow, they are more likely to end up staying homeless.

One participant noted that "we need to connect where resources are and where affordable housing is. Folks do not want to live far from where the resources are." Because the LGBTQ community is more central, and if someone is forced out to the edge where it may be more affordable, they are forced out of the community they so badly need and into a possibly more homophobic area.

How can the current design of shelters in the city better reflect the needs of LGBTQ homeless youth?

Interviews with participants revealed that the current design and location of facilities did not meet the needs of the LGBTQ homeless population. For the homeless community, it is important to have gender separation for beds. The binary separation of male and female does not incorporate those who identify as trans or queer or twospirited, or anything other than male or female, leaving a very large proportion of the homeless youth population either entering establishments where they do not feel safe, making the decision to remain out on the streets. 
This is exacerbated when the initial point of contact for LGBTQ homeless youth is negative. One participant noted that, "they are just trying to stay there to sleep for a night, and for them it becomes a not restless night."

What are the challenges to siting new shelters and assisted housing units? And how can we alter the current design and approach to the siting of shelter and support facilities?

In Toronto, the Church-Wellesley neighbourhood is the central village for the LGBTQ population in the city. But in recent years the village has become more decentralized, spreading west. And the region itself has grown, with over 3 million people surrounding Toronto.

One frontline employee stated that, "It cannot be just a rainbow sticker on an office window. We need to make them [services] accessible in various parts of the city. A shelter that is queer and trans is important, but one is not the ideal solution because we cannot just send everyone there, as the population is spread over the city."

Solutions need to be citywide. Addressing the issue in one location, though a step in the right direction, fails to address the deficiencies in service delivery in other parts of the city. An interview with a policy official noted that you cannot over saturate an area with shelters and affordable units otherwise market paying people will leave and you will end up with an unfavorable area. Urban planners need to see what has worked and what has not, and work towards spreading units across the city and the region to keep people in their communities.

One policy worker noted that it was largely a funding constraint and that, "We need a shift in the limited resources available from shelters to more permanent housing. Shelters are acting as defacto housing for three to five to seven years, with shelters becoming not temporary housing but becoming a 
home for some. Shelters are more costly to run than other forms of affordable housing where tenants would have access to medical resources."

They further noted that we need to stop having these "thousands of dollars emergency response calls" where all uniforms show up to assess a homeless person lying on the sidewalk. Answers need to be built with frontline workers, as they know what's going on, and neighbourhoods as they have to live with their new neighbours.

The policy worker also stated they wanted to see inclusionary zoning legislated, not just at the municipal level, but also supported at the provincial level. They outlined concerns where developers would overturn regulations in the municipalities Official Plan and Zoning By-Laws at the Ontario Municipal Board, and that legislation and support from the province would make this more difficult. The interviewee stated that the current Section 37 negotiated community benefits was a, "crap shoot," and did not provide any consistency or reliability for any parties involved. Developers all want a level playing field, and do not want anyone to have advantage over one another. This provincially led legislation would make it fairer and provide consistency and reliability to all parties involved. 


\section{0 - Discussion}

Interviews with participants brought to light several areas where frontline workers and policy officials felt that the current system of outreach and support for LGBTQ homeless youth was failing. Language and first interaction with homeless youth; the mental and physical health of LGBTQ homeless youth due to a lack of services and difficulty navigating services offered; policies from both provincial and municipal governments on homelessness and securing units to add to the portfolio of assisted and transitional housing; funding of the current system and the attainment of new funds for shelters, assisted housing, and transitional housing; the clustering of shelters and housing units creating deficiencies in other parts of the city; all of which are compounded by a lack of political support.

Language is the most important starting point for this subject. How can someone expect to intervene in an issue if they cannot connect with the issue? Diversity training and an understanding of the struggles faced by the LGBT homeless youth community bring to light what LGBTQ homeless youth require from the shelter and support system, building solutions from the bottom-up rather than top-down.

From interviews with frontline workers, knowing how to tackle homophobia, being comfortable talking with a young queer youth, and understanding the unique mental challenges they face, can work towards creating a comfortable place for LGBTQ youth so they do not turn away from the system because their first interaction with a frontline worker is negative. This first interaction is critical to helping their mental and physical health. As noted in the interviews, the mental and physical health of LGBTQ homeless youth was worse than their heterosexual counterparts as they have higher rates of depression (Ray, 2006), anxiety(Ray, 2006), substance abuse (van Leeuwean, et al., 
2006), and survival sex (CMHC, 2001). Professionals interviewed recognize the issues faced by this population, but they represent a subset of the outreach workers. More needs to be done to engage all service providers to both engage and assist LGBTQ homeless youth.

Social planning policies and interventions are limited by the planning process, funding, and political will. As Toronto and the province make cuts to social programs, funding for such specific initiatives has to become more politically viable as the public wants to see the greatest impact with the limited amounts of funds being spent. Policy will have to guide decision-making, as politicians make decisions based on problems with solutions and measureable facts.

The best policy positions are those that can analyze the issue and offer realistic solutions (NICVA, 2011), Toronto currently lacks holistic approach to the issue of LGBTQ youth homelessness. While Toronto has recognized that there is a homeless issue in the city, and recognized that there are LGBTQ homeless youth on the streets by mentioning the health initiative championed by the Sherbourne Health Centre, there is still a deficiency of programs aimed at helping the approximatly $25-40 \%$ of homeless youth that identify as LGBTQ (Josephson \& Wright, 2000). This proportion of the population, 40\%, was echoed in one interview with a frontline worker. Comprising a disproportionate amount of the homeless youth population, LGBTQ youth must have greater acknowledgement and representation in services directed at alleviating youth homelessness, as was echoed in several interviews with professional participants.

Policy changes need champions, someone to spearhead the change and who have the ability to influence colleagues and the minds of others (Devlin-Foltz \& Molinaro, 2010, p. 
8). A substantive understanding of how many homeless youth are on the streets coupled with a person of power who has interest in the cause will be the only viable way to putting LGBTQ youth homelessness back on the political agenda and into guiding policies.

The current policy lacks measurable indicators and a time frame to track progress on actions plans by which to assess the effectiveness of the policy in place. Without having an understanding of the severity of the issue, the lack of an action plan makes sense, as the City needs a starting point from which to tackle the problem. Adding to the inability of service providers to start making a difference is the lack of clearly identified funding for specific programs, shelters, or out reach programs run by the City, and a lack of clearly available and accessible information for youth to navigate towards support services directed at them. Each frontline worker noted that they reference youth that come to them to other services, but information from the city was confusing and hard to decipher.

The lack of funding for LGBTQ specific programs is also a function of two variables; competition for limited available funds, and a lack of political will and interest. Policy workers and frontline workers echoed this as they see numerous organizations competing for limited funds and decisions being made based on the political flavour of the time. Reiterated by one policy worker, there needs to be a shift in focus in providing for the homeless, as shelters were not meant to act as long-term housing. There needs to be political will to shift funds around, even within the shelter system itself, to provide for more long-term spaces such as assisted and transitional housing. 
Policy needs to be firmly rooted in political support. If private sector development funds are to be secured and stand the test at Ontario Municipal Board hearings, legislation needs to be enacted by not just municipalities, also the Province of Ontario. With Ontario being a provincially led planning system, the province can lend much needed legal policy support to municipalities by enacting policy province wide to ensure stronger policy frameworks to support the construction of shelters, transitional and assisted units in municipalities where zoning specifies.

The current method of securing community benefits from private developments in Ontario, Section 37 benefits for increased density, is a shot in the dark and unpredictable when it comes to attaining benefits. Negotiation provides little predictability for all parties involved and has delivered little to no affordable, transitional, or assisted living spaces. As noted by the policy worker, no developer wants an uneven playing field, and they all want to be treated fairly. Enacting provincial legislation surrounding shelters, transitional an assisted housing, and support facilities, will ensure that not only are standards fair across all municipalities, but may assist in providing more reliable delivery of needed units.

With effective policy in place, projects such as an LGBT focused shelter, assisted and transitional housing, and health and wellness support, we can begin to assist in getting queer youth off the streets and into a system of care that has the capacity to help them with their unique emotional needs. As they quickly become the fastest growing segment of the youth homeless population (Josephson \& Wright, 2000), effective policy is needed now, proactively, rather than as a reaction to a catastrophic occurrence as the system continues to fail this disadvantaged population. 
The current system of municipal planning tools - zoning by-laws and public consultations - favours existing owners, land uses and visions for a specified area, of which, shelters are never envisioned. It gives greater weight on decisions to individual rights based interests rather than the more diffuse idea of a public interest. This is exemplified in the new visions for the Urban Growth Centres outlined by each municipality that enacts a vision, master plan, or secondary plan, where there is no inclusion of community support services by way of homeless shelters, food banks, or transitional and assisted housing units.

Currently in Toronto, in the zoning by-laws, there is no inclusion for shelters, support services, transitional, and assisted housing units. Because rights travel with the use and not with the person, social planning decisions are further limited by zonings current inability to legally include shelters in their provisions. Toronto needs to better utilize land use planning regulation process to build legal support and aid in the siting of shelters and assisted housing units, supported by provincial legislation. Inclusion in the legal status of the zoning by-law would give greater as-of-right development capabilities to the municipality and service providers.

There is still fear of shelters and support facilities, which becomes evident in public consultations as neighbourhing property owners fear a declining property value, harm to their neighbourhoods or streets charm or character, or harm to themselves because of, 'the people they will attract' (Ranasinghe \& Valverde, 2006, p. 329). Planners should realize the limitations and bias that arise in public consultations, and should do more to include the interests of those not represented by land titles in the discussion and decision making process by expanding the dialog surrounding the needs of not only 
LGBTQ homeless youth, but all disadvantaged street populations that would benefit from such services.

In designing the overall system of shelters and support, actions should be spread across the city. Connecting the places where people live and the services they require is paramount. Shelters and support services should be located near where people need them, and in Toronto, that extends beyond the central city. One policy worker noted that it is not fair to cluster all affordable units and shelters in one ward as too many units may negatively impact a community and drive other renters and owners out.

As the LGBTQ population is not just located in the Church-Wellesley neighbourhood, actions need to extend beyond this area. One or a few highly accessible locations can be chosen for the highest forms of infrastructure interventions (LGBTQ focused shelter), while transitional housing units and support services for LGBTQ homeless and precariously housed youth can be implemented across the city and the region. Staff in existing outreach organizations across the region, and teachers in elementary and highschools, can be trained in LGBTQ issues, to provide the needed positive first interaction with the youth.

But none of this can be accomplished without political will. Planning is an inherently political activity. As part of the municipal decision making process, planners give their professional assessments and opinions to that of municipal councilors who make the final decisions. As voters within a councilors ward (those with a fixed address) often have the greatest influence on a councilor, it becomes difficult to appeal to councilors interests if there is no political gain and/or re-election prospect. An unfavourable or unwanted policy position may decrease their popularity within their riding. No social 
justice issue can move forward in policy and action without the support and funding from political decision-making. Politicians and planners need to connect with communities, connect with neighbourhoods, connect with individuals, to build consensus and break down the stigma's associated with shelters, transitional housing and assisted housing units, and the stigmas associated with this population.

Helping LGBT youth homelessness shouldn't just start once they are on the streets, but should begin earlier in schools to help erase irrational homonegativity for both youth and their parents. The fear stems from not fully understanding homosexuality, and seeing it as presenting a hidden danger to heterosexuals (Sharpe, 2002). Gay-Straight Alliances in schools can help to break down barriers and stereotypes, exposing people to new social and cultural experiences. The Toronto District School Board (TDSB) is using a handbook created by Gale-BC that helps schools to establish and understand the positive implications of Gay-Straight Alliances. Gale-BC advocates for change in the educational system, which results in a positive environment for lesbians, gays and bisexuals in education, whether they are students, parents, teachers, or administrators. And with $80 \%$ of LGBT youth stating they faced abuse at school, further increasing their likelihood of becoming homeless (Ray, 2006, p. 20), positive classrooms are the first chance to provide a safe space for closeted and newly-out LGBT youth. 


\section{0 - Recommendations and Conclusions}

Coming out of the closet is never easy; it is exponentially more difficult when it leads to the possible eviction from your current life and support systems. Being homeless exacerbates existing life issues while adding on numerous new ones. And while being homeless is never an easy experience, LGBTQ homeless youth are at a greater disadvantage than their heterosexual counterparts. With the increased health concerns for LGBTQ homeless youth, action is required to address the deficiencies of current policies, land use planning tools, and shelter and support systems are not designed to address the stigmas and hate directed at LGBTQ homeless youth.

Urban planning's successes and failures in intervening in social issues have illustrated the professions capacity and multi disciplinary abilities to remedy social problems. Being able to build a digestible understanding of the larger issues at hand, addressing it through policy, land use planning tools, politics, and societal consciousness, gives planners rich perspective on how to aid in the provision of services for LGBTQ homeless youth.

While there has been some work done to quantify the problem and begin to build solutions for LGBTQ youth homelessness, there needs to be further research to properly assist this rapidly increasingly visible population.

\section{Language}

With the LGBTQ population moving further into mainstream society, gaining full rights and recognition from governments, employers, and society, the unique issues faced by this population will shed further light as less and less LGBTQ identified people feel the need to hide their sexuality. 
There needs to be a firm starting point of an understanding of the severity of the problem of LGBTQ youth homelessness by the City, with a focus on developing need specific programs and projects targeted at homeless queer youth. In order to further assist the LGBTQ homeless youth population in Toronto, further research needs to be conducted to:

1. Understand the number of LGBTQ homeless youth in the city and to provide measurable indicators to monitor progresses and change in the population; and

2. Conduct interviews with LGBTQ homeless youth to understand their needs and the barriers they face based on their interactions with the current shelter and support services providers.

\section{Policy and Funding}

Programs need to have a clear vision and funding to implement the objectives laid out in the policy, with the means to measure and track the objectives over a specified timeframe if they are going to assess the effectiveness of the current policy in place. Localized service actions that can drastically improve first interactions with the system, need to be undertaken to assist LGBTQ homeless youth:

1. Mandatory diversity training and language skills for all frontline and policy workers to provide better first interactions with the support system;

2. Creation of programs in all current outreach organizations for LGBTQ homeless youth across the city; and

3. Creation of school education programs by the outreach organizations to both further program providers diversity training while educating young people and their parents about LGBTQ people.

Policy is a starting ground for greater changes to be made to assist this population, as it lays out the overall objectives. Currently there exists policy that recognizes homelessness and youth homelessness in the City of Toronto, and there are clear programs and projects being undertaken to improve the lives and outlook of homeless youth, but land use planning tools restrict the creation of new shelters and support 
services. To become effective, planning policy and land use planning tools, several changes need to be reviewed:

1. Policy needs to be enacted that recognize the distinct issues faced by the LGBTQ homeless youth population;

2. Policies that support land use planning tools and objectives need to be strengthened through provincial support;

3. Review the policies and process for attaining new transitional and assisted housing units from private developments to provide clear, fair, and predictable contributions; and

4. Study the possibilities to shift funding around in the shelter and support budget to support the creation of more assisted and transitional housing units.

\section{Land use Planning Tools}

Policy is both a reflection and direction of where a government is headed, and land use planning tools are the method to implement those policies. Current polices and tools do not adequately address the issue of LGBTQ youth homelessness in the City of Toronto. Policies need to be implemented by land use planning tools in order to properly aid in the provision of services and spaces for LGBTQ homeless youth. Action needs to be taken to:

1. Pressure the province to strengthen its role in the provision and procurement of shelters, transitional and assisted units;

2. Reinforce and further provincial policies through municipal inclusionary zoning, giving greater as-of-right development provisions to the creation of shelters, transitional and assisted living units;

3. Realize the limitations in public consultations in their ability to generate acceptance or consensus regarding the siting of new shelters, support facilities, assisted and transitional housing units and look towards new methods of engaging communities.

If we are to influence people and move towards a more inclusive society, we need to focus on finding proactive solutions to our issues. The basic knowledge exists. We need to recognize that the LGBTQ homeless youth issue can be addressed not only in one facet of the support system in Toronto, but through numerous actions from policy, programming, education, marketing, and the planning process. 
"It takes a village to raise a child." The coordinated actions of many actors are needed to properly rectify the issue and aid in the provision of services for LGBTQ homeless youth. Remembering nothing can be done without political support and community backing, the issue of LGBTQ youth homelessness is going to be rectified, current policy needs to adequately address the issue at hand, and implement a program and targeted projects both for the shelter and support system, as well as outreach programs to schools and parents to reduce homonegativity. 


\section{0 - Limitations}

Although the research was carefully conducted, there were a few unavoidable limitations. First, the number of interview participants was limited by the short study period. Lengthening the study period to be able to attain more interviews with professionals would be beneficial to providing a wider view on the subject.

Furthermore, extending the interviews to LGBTQ homeless or precariously housed youth would add another critical viewpoint to the topic, attaining first hand accounts from the youth on their interactions with the current shelter and support system. It would also assist in building solutions from the bottom-up, working with the youth to build the system that is attempting to support this population. 


\section{0 - Works Cited}

Abadalian, S. E. (2004, August). Street youth more likely to die of suicide and drug overdose. Journal of the American Medical Association .

Akkar, M. Z. (2005). Questioning Inclusivity of Public Spaces in Post Industrial Cities: The Case of Haymarket Bus Station, Newcastle Upon Tyne. METU JFA , 22 (2), 1-17.

Ali Forney Center. (2012). Housing for Homeless LGBT Youth. Retrieved 11 19, 2012, from Ali Forney Centre:

http://www.aliforneycenter.org/index.cfm?fuseaction=cms.page\&id=1006

Berberet, H. (2006). Putting the Pieces Together For Queer Youth: A Model for Integrated Assessment of Needs and Program Planning. Child Welfare , 85 (2), 361-384.

Boyle, T. J. (2009). The experiences of homeless lesbian, gay, bisexual, and transgender youth and the meanings attached to these experiences. ProQuest Dissertations and Theses .

BUILD Toronto. (2009). Annual Report. City of Toronto, Toronto.

Butt, N., De Gaetano, R., \& Thompson, R. (2004). Homelessness In Toronto - A Review of the Literature from a Toronto Perspective. Retrieved 04 01, 2013, from The Homeless Hub: http://www.homelesshub.ca/library/homelessness-in-toronto---a-review-of-theliterature-from-a-toronto-perspective-53932.aspx

Canadian Community Health Survey. (2012, 11 28). Gay Pride - By The Numbers.

Retrieved 04 04, 2013, from Statistics Canada:

http://www42.statcan.gc.ca/smr08/2011/smr08_158_2011-eng.htm

City of Toronto. (2008). How Toronto is Solving Youth Homelessness. Shelter, Support, and Housing Devision. Toronto: City of Toronto.

City of Toronto. (2004, 02 04). Public Consultations. Retrieved 03 23, 2013, from City of Toronto:

http://www.toronto.ca/wes/techservices/involved/wws/biosolids/pdf/meeting_9_pub lic_consultation_plan.pdf

City of Toronto. (2009). Toronto Housing Charter: Opertunity for All. Affordable Housing Committee. Toronto: City of Toronto.

CMHC. (2001). Environmental Scan on Homeless Youth. Research Highlights , 86, 1-3.

CMHC. (2002). Innovative housing for homeless youth. Socio-Economic Series , 108, 4.

CMHC. (2012). Land Leases. Retrieved 11 3, 2012, from CMHC: http://www.cmhcschl.gc.ca/en/inpr/afhoce/tore/afhoid/fite/lale/lale_001.cfm 
Cowan, B., Gewirtz, A., Haskett, M., Perlman, S., \& Stokes, L. (2012). Promoting Positive Parenting in the Context of Homelessness. American Journal of Orthopsychiatry , 82 (3), 402-412.

Devlin-Foltz, D., \& Molinaro, L. (2010). Champions and “Champion-ness”. Centre for Evaluation Innovation.

Dwelly, T., \& Cowans, J. (2006). Rethinking Social Housing. The Smith Institute.

Emsley, S., Phibbs, P., \& Crabtree, L. (2008). Models of Sustainable and Affordable Housing for Local Government. University of Western Sydney, Urban Research Centre.

Fullarton, F. (2004). Public Private Partnerships for Affordable Housing. ING Direct, ING Hague Bursary.

Greenberg, G. (2007). Gay by Choice? Mother Jones , 32 (5), 61-94.

Griffin, L. (2004, January). Creating Affordable Housing in Toronto Using Public Private Partnerships. FES Outstanding Graduate Student Paper Series, 9 (2).

Hall, D., Lethbridge, J., \& Lobina, E. Public-public partnerships in health and essential services. University of Greenwich, Public Services International Research Unit, . Regional Network for Equity in Health in Southern Africa.

Hein, L. C. (2011). Survival Strategies of Male Homeless Adolescents. Journal of the American Psychiatric Nurses Association , 17 (4), 274-282.

HRSDC. (2005). Youth Profile Toronto/York Service Delivery Sector Human Resources Development Canada. Toronto.

Hunter, E. (2008). Whats Good for the Gays is Good for the Gander: Making Homeless Youth Housing Safer for Lesbian, Gay, Bisexual and Transgender Youth. Family Court Review , 46 (3), 543-557.

Josephson, G., \& Wright, A. (2000). Ottawa GLBT wellness project: Literature review and survey instruments.

Kemp, P. A., \& Neale, J. (2005). Employability and problem drug users. Critical and Social Policy , 25 (1), 28-46.

Kerkin, K. Designing a Social Space. Australian Planner , 37 (2000), 35-38.

Kitchen, H. M. (2002). Municipal Revenue and Expenditure Issues in Canada. Toronto, ON, Canada: Canadian Tax Foundation.

Kuzmak, N., \& Muller, L. (2010, Winter). Siting Homeless Shelters in Calgary: Impacts of the New Land Use Bylaw and the Local Development Process. Canadian Journal of Urban Research , 1.

Lammers, J., \& Stapel, D. A. (2011). Power increases dehumanization. GPIR , 14 (1), $113-$ 126. 
Leduke, N. W. (2009, 05 22). The Salvation Army in Toronto Celebrates the Opening of the New \$35 million Harbour Light Ministries Building. Retrieved 11 15, 2012, from Toronto Affordable Housing: http://www.toronto.ca/affordablehousing/pdf/harbour_light.pdf

Lehrer, U., \& Winkler, A. (2006). Public or Private? The Pope Squat and Housing Struggles in Toronto. Social Justice , 33 (3), 142-157.

Mah, J. (2009). Can Inclusionary Zoning Help Address Shortages of Affordable Housing in Toronto? Canadian Policy Research Networks, Toronto.

Mah, J., \& Hackworth, J. (2011). Local Politics and Inclusionary Housing in Three Large Canadian Cities. Canadian Journal of Urban Research , 20 (1), 57-80.

Ministry of Municipal Affairs and Housing. (2012, 05 22). Governments of Canada and Ontario Celebrate New Affordable Housing in Toronto with YWCA. Retrieved 11 15, 2012, from News Ontario: http://news.ontario.ca/mah/en/2012/05/governments-of-canadaand-ontario-celebrate-new-affordable-housing-in-toronto-with-ywca.html

Ministry of Municipal Affairs and Housing. (2012, October 11). Pan and Parapan Am Games to Create Affordable Housing Legacy. Retrieved November 15, 2012, from Ontario News Release: http://news.ontario.ca/mah/en/2012/10/pan-and-parapan-am-gamesto-create-affordable-housing-legacy.html

Ministry of Municipal Affaris and Housing. (2010, 10 20). Land Use Planning - Zoning ByLaws. Retrieved 03 25, 2013, from Ontario Ministry of Municipal Affairs and Housing: http://www.mah.gov.on.ca/Page1758.aspx

Moskalyk, A. (2008). The Role of Public-Private Partnerships in Funding Social Housing in Canada. Canadian Policy Research Networks. Scoial Housing Services Corporation.

Neuman, L. W. (2003). Social Research Methods: Qualitative and Quantitative Approaches. Boston, MA, USA: Pearson Education INC.

NICVA. (2011). How to do a Policy Analysis. NICVA, Combat Poverty Agency, Belfast.

OMNI. (n.d.). The Shoeshine Boy. Retrieved 03 03, 2013, from Language Docs: http://www.omnibc.ca/programming/languagedocs/details.php?id=146

Ordover, N. (1996). Eugenics, the gay gene, and the science of backlash. Socialist Review, $26(1-2), 125-144$.

Ranasinghe, P., \& Valverde, M. (2006). Governing Homelessness Through Land-use: A Sociolegal Study of the Toronto Shelter Zoning By-law. Canadian Journal of Sociology , 31 (3), 325.

Ray, N. (2006). Lesbian, Gay, Bisexual, Transgener Youth: An Epidemic of Homelessness. 199. New York, USA: National Gay and Lesbian Task Force Policy Institute and the National Coalition for the Homeless. 
Reck, J. (2009, August 14). Homeless Gay and Transgender Youth of Color in San Francisco: "No One Likes Street Kids"-Even in the Castro. Journal of LGBT Youth , 223242.

Ruth Ellis Center. (2012). Youth Programming . Retrieved 11 15, 2012, from Ruth Ellis Center: http://www.ruthelliscenter.org/programs

Scheyvens, R., Scheyvens, H., \& Murray, W. (2003). Working with Marginalised, Vulnerable or Privileged Groups. In S. Regina, \& D. Storey, Development Fieldwork. SAGE Publications Ltd.

Sharpe, S. (2002). Its Just Really Hard to Come to Terms With: Young peoples views on homosexuality. Sex Education , 2 (3).

Shelter, Support and Housing Administration . (2012). Homelessness Partnership Strategy . Retrieved 12 15, 2012, from City of Toronto: http://www.toronto.ca/housing/about-hpi.htm

Skelton, I. (1996). The Geographic Distribution of Social Housing in Ontario, Canada: Comparing Public Housing and Locally Sponsored, Third Sector Housing. Housing Studies , $11(2)$.

Tarantello, R., \& Seymore, J. (1998). Affordable Housing Through Non-Profit/PrivatePublic Partnerships. Real Estate Issues , 23 (3), 15-17.

Toronto Community Housing . (2012). Regent Park. Retrieved 11 15, 2012, from TCHC: http://www.torontohousing.ca/regentpark

Toronto Community Housing. (2012). Building a Plan in Alexandra Park. Retrieved 11 15, 2012, from TCHC:

http://www.torontohousing.ca/investing_buildings/alexandra_park

True Colors Residence. (2011). True Colour Residence. Retrieved 11 19, 2012, from West End's Residences: http://westendres.org/true-colors-residence-2/

van Leeuwean, J., Boyle, S., Salmonsen-Sautel, S., Baker, D. N., Garcia, J., Hoffman, A., et al. (2006). Lesbian, Gay, Bisexual Homeless Youth: An Eight-City Public Health Perspective. Child Welfare , 85 (2), 151-170.

Walls, N. E., Potter, C., \& Van Leeuwen, J. (2009). Where Risks and Protective Factors Operate Differently: Homeless Sexual Minority Youth and Suicide Attempts. Child and Adolescent Social Work, 26, 235-257.

Waytz, A., \& Epley, N. (n.d.). Social connection enables dehumanization. Journal of Experimental Social Psychology.

YWCA. (2010). About Us. Retrieved 11 15, 2012, from YWCA:

https://www.ywcatoronto.org/page.asp?pid=58 
YWCA Elm Centre. (2012, 05 12). YWCA Elm Centre Fact Sheet. Retrieved 11 15, 2012, from YWCA Toronto: https://www.ywcatoronto.org/files/1339525837016-YWCAElmCentre-FactSheet.pdf 